\title{
Influence of the biopreparation "Gaupsin" on storability of mandarin fruits
}

\author{
${ }^{1}$ Zurab Mikeladze, ${ }^{2}$ Nunu Kutaladze, ${ }^{3}$ Shota Lominadze
}

Chief Scientific Officer, Doctor of Science in Agriculture

Senior Scientific Officer, Doctor of Science in Agriculture

Associated Professor, Doctor of Science in Agriculture

\author{
Batumi Shota Rustaveli State University \\ Institute of Agrarian and Membrane Technologies \\ Submitted by the Academician Vano Papunidze
}

\begin{abstract}
:
Our goal is to incorporate in the complex of citrus agrotechnical activities such technologies that will significantly increase the natural storability of mandarin fruits, in production and in short time in normal conditions, in the process of storage and sale. To this end, we conducted a large-scale experiment and included in the complex of agrotechnical measures the biopreparation "Gaupsin" of Ukrainian production, which protects plants from pests and diseases, promotes their growth and development, improves fruit bearing and qualitative indicators, in their number, increasing of storability. Gaupsin, as a bacterial fungicidal preparation, exhibits insecticidal properties, destroys pests, and with these and other properties, Gaupsin allows us to obtain high-quality and storable mandarin fruits. Its use is effective for processing of containers and boxes. At the same time, the preparation is environmentally friendly. Use of the biopreparation Gaupsin has shown a tendency to improve agrochemical parameters of soil; yield and quality parameters significantly increase. The parameters of adverse action of pests and diseases (especially silver mites and anthracnose) decreased to minimum. Natural fruit storability increases, at the cost of improvement of general physiological condition of fruits and neutralization of the pathogen, which shows the positive impact of the biopreparation in terms of fruit bearing. It should also be noted that the use of Gaupsin has practically eliminated the alternating bearing of mandarins and we every year obtain quantitatively and qualitatively stable harvest.

During the experimental period, we monitored the spread of pest disease on a monthly basis by means of commissions, focusing on monitoring the spread of such pests that significantly harm the growth and crop quality of mandarin. These include silver mites (4045\% harmfulness), citrus red mites Panonychus citri (45-50\% harmfulness), elongated grey citrus scale (20-25\% harmfulness), anthracnose (20\%), wart disease (25\%), black spots (25$30 \%$ ). They each damage leaves, fruits, twigs and buds of plants. Anthracnose is particularly potent in conditions of fruit storage. The blackness caused by the fungal excretion of saprophyte fungi inhibits plant respiration and photosynthesis processes. The crop decreases and fruit loses its commodity, so these fruits are most easily damaged during storage by fungi of penicillium group and they spoil as quickly as possible. Losses from fruit
\end{abstract}


breakdown are so significant that such fruits are virtually unusable not only for fresh consumption, but also from the point of view of industrial processing. At the same time, the environment is heavily polluted and it is also dangerous in subsequent years.

Based on our experimental data, we have developed calibrator for mandarin fruit and a mobile device for processing with Gaupsin, which has been handed over to newly established cooperatives. Serial manufacturing of such simple machine will resolve the problem of commodity processing of mandarin fruit by the biopreparation Gaupsin, and the farmer will be able to obtain on the spot products storable in commodity state, and the retailer will be guaranteed to minimize losses during the transportation and sale.

\section{Introduction:}

The storability of citrus fruits is one of the key factors of their quality that has received little attention in our reality. In this regard the most important loss is of mandarin fruits during the processes of storage, transportation and sale. More than $20 \%$ of the produced fruit is lost during transportation and storage for a short time under normal and even stationary storage conditions and cannot reach the consumer $[1,2]$. The storability of mandarin fruits depends on many factors, including the complex agrotechnical measures, variety characteristics, soil exposure, soil type and fertility, the technology of picking and processing, means and modes of storage and transportation. The limited harvesting time does not allow the farmer to fully comply with all agrotechnical and commodity processing technologies. Problems with the realization in the short-term of a large number of matured mandarin fruits, even industrial processing, is associated with a number of difficulties, and the result is truly detrimental to both the farmer and the retailer businessman [3, 4]. The essence of the problems lies in the fact that the breathing process is very intensive in mandarin fruits after harvesting, which intensifies the process of metabolism, and excretion of temperature and accumulation of ethylene, which results in a faster entering of fruits in the stage of biological maturity and activation of pathogenic microorganisms, resulting in increasing of natural and total losses, significantly damaging primarily the farmer, retailer and the whole sector economy $[5,6]$. In order to eliminate the above-mentioned problems in world practice there are widely established the technologies of washing of fruit, disinfection and processing with film coating preparations, pre-cooling and storage of fruit in refrigerators for short-term and longterm storage. At the same time, the technologies of storage of fruit in refrigerated and regulated gases conditions, as well as storage in stationary warehouses are widely introduced. It should also be noted that orange fruits make up more than $80 \%$ of the world production of citrus; their storability is significantly higher than that of mandarins, and the implementation of these technologies does not have the desired effect on mandarins $[7,8]$.

\section{Method and object:}

Therefore, our goal is to incorporate in agrotechnical complexes such technologies that will significantly increase the natural storability of mandarin fruits, in production and in short time under normal conditions, during storage and sale $[9,10]$. To this end, we conducted a large-scale experiments: in the complex of agrotechnical measures has been included the biopreparation Gaupsin, of Ukrainian production, developed by the Microbiology and Virology Research Institute of the Ukrainian Academy of Sciences that is widely used in the agrotechnology of production and processing of fruit and vegetable $[10,11,12]$. This preparation has not been registered in Georgia yet, so in 2014 we have submitted the 
application to the National Food Agency of the Ministry of Agriculture of Georgia to import the pilot batch of preparation with the purpose of conduction of experiments. Our request has been satisfied and we have imported the preparation "Gaupsin" with various periodicity. The preparation Gaupsin is based on a combination of the industrial strains of bacteria Pseudomonas aureofaciens B-206, B-111 and protects plants from pests and diseases, promotes their growth and development, improves productivity and quality parameters, including increased storability. The research by Ukrainian scientists has shown that Gaupsin promotes the transition of the hardly soluble nutrients in the soil to the state assimilable for plants; suppresses pathogenic microorganisms by excreted indole acetic acid, promotes the propagation in soil of rhizobia, fixing atmospheric nitrogen through them and providing the plants with atmospheric nitrogen. In one year, $200-300 \mathrm{~kg}$ of nitrogen is accumulated per hectare. Gaupsin, as a bacterial fungicidal preparation, also exhibits the insecticidal properties, destroys pests; due to these and other properties, Gaupsin allows us to obtain high-quality and storable mandarin fruits. Its use is effective in the processing of containers and boxes. At the same time, the preparation is environmentally friendly $[13,14,15,16,17]$.

\section{Experimental part:}

In 2014-2017 we studied the effectiveness of "Gaupsin" in the stationary field experiments in the mandarin garden, spraying on the plant and sprinkling the soil. During the vegetation period, once per month we used one portion of the preparation diluted in 501 of warm water. Trials were repeated 6 times in triplicate, and in the variant, there were 18 plants.

The scheme of experiment was as follows:

1. NPK by agronomical regulations

2. NPK by 0.5 of agrotechnical dose

3. NPK 0.5 agrotechnical dose + Gaupsin sprayed, in vegetation period once monthly.

4. Gaupsin sprayed once monthly

5. Gaupsin sprayed 10 days earlier the harvesting of fruits

6. Gaupsin sprayed on fruits before storage.

We used as fertilizer NPK of Russian production with 15-15-15\% contents of nutrients. Gaupsin was dissolved in water 1:50. Tests were conducted in the beginning and before the harvesting. In the autumn we have taken soil samples at a depth of $0-40 \mathrm{~cm}$ and determined the agrochemical parameters. At the same time, monthly before sprinkling of Gaupsin we took soil samples at 0-20 cm depth and determined nitrogen contents. At the beginning of the first and second vegetation, we took leaf specimens from the middle tier of the test plant to the last shoot from the growth cone down to the 3-rd and 4-th leaves and determined the agrochemical indices (Table 1). During the vegetation period, we monitored plant diseases at the end of each month by means of commission. In autumn in the stage of fruit ripening, we picked the fruits and weighed per each test plant. In addition to the mentioned, we had a model plant in each of these units, from which we obtained 3 boxes of fruits visually identical in size. In each box, we kept the same number of fruits and stored them in a specially designated room at temperatures of $10-15^{\circ} \mathrm{C}$, inspecting the stored fruit every 15 days. We weighed, estimated natural losses and counted the number of healthy and infected fruits (Table 2,3)

\section{Results and discussion:}


Table 1. Agrochemical parameters of soil before beginning of experiment, 2014

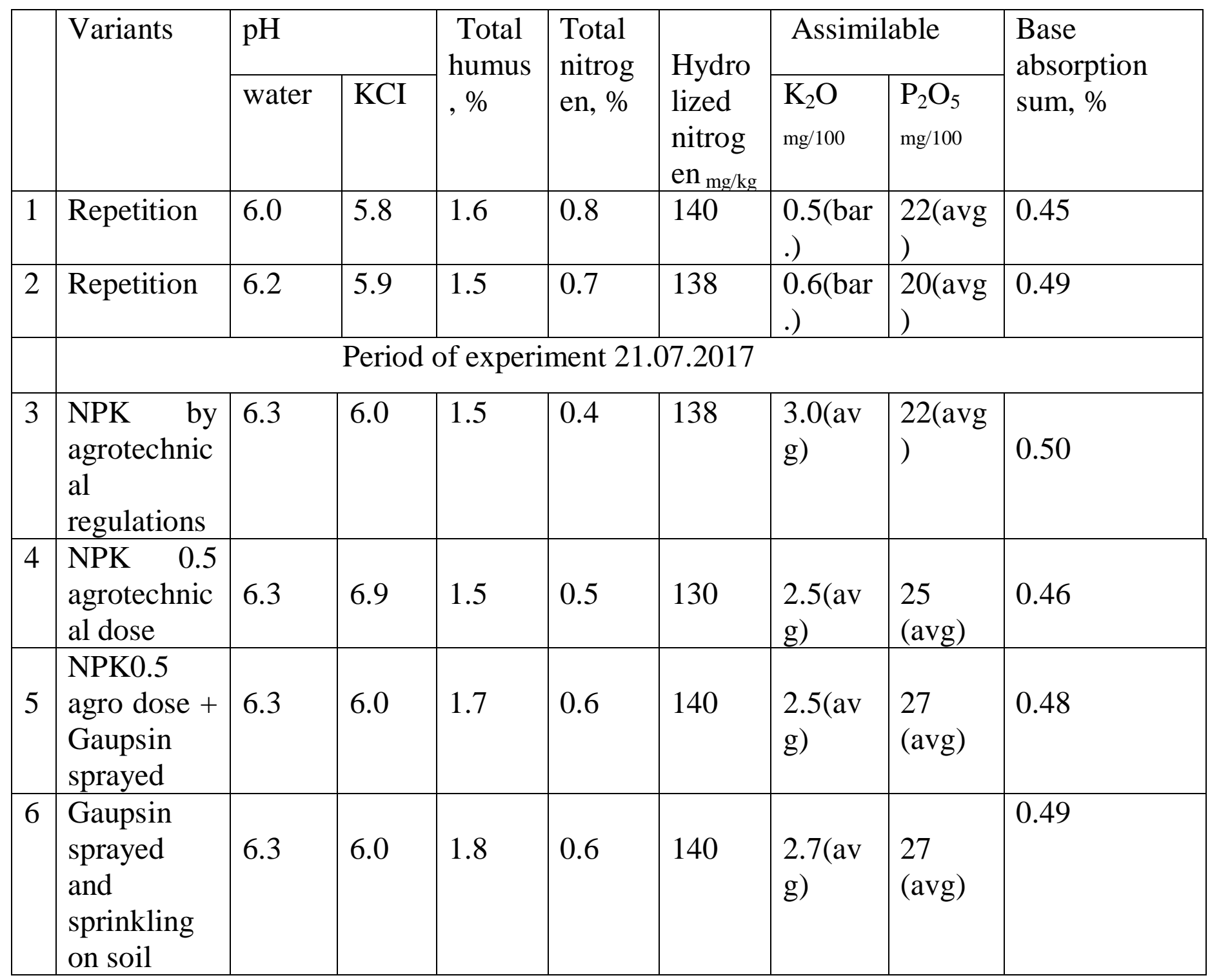

Agrochemical analyzes of soil samples were carried out according to the following methods: total humus by Tiurin method GOST 25336-82, total nitrogen by micro chromium method GOST 22268-89, hydrolytic nitrogen by Tiurin and Konanova method GOST 22267-88, assimilable phosphorus by Oniani method GOST 26206-91, assimilable potassium by the device SOIL TEST-500 and Oniani method, GOST 1985: 228-295, pH determination in water and KCI extracts by GOST 27753.3-88, base absorption sum by Kappen method.

As can be seen from the table, before the experiment $\mathrm{pH}$ of the soil was characterized by a weak acidic reaction, which was caused by use of defecation mud ( $15 \mathrm{~kg}$ per 1 plant) 3 years before the test. Total humus is within the range of $1.5-1.6 \%$. The NPK rate is also low. There is no significant increase in the basic soil agrochemical indices during the test period.

Table 2. Mandarin yield in $\mathrm{kg}$, average per one plant

\begin{tabular}{|l|l|l|l|l|l|ll|}
\hline Variants & 2014 & 2015 & 2016 & 2017 & $\begin{array}{l}\text { In } \\
\text { total }\end{array}$ & $\begin{array}{l}\text { Average per } \\
\text { plant }\end{array}$ \\
\hline NPK & by & 43 & 50 & 45 & 52 & 120 & 48.5 \\
\hline
\end{tabular}




\begin{tabular}{|l|l|l|l|l|l|l|}
\hline $\begin{array}{l}\text { agrotechnical } \\
\text { regulations }\end{array}$ & & & & & & \\
\hline NPK 0.5 agro. dose & 38 & 45 & 43 & 45 & 194 & 45.0 \\
\hline $\begin{array}{l}\text { NPK 0.5 agro. dose } \\
\text { +Gaupsin sprayed }\end{array}$ & 52 & 54 & 48 & 50 & 204 & 51.0 \\
\hline $\begin{array}{l}\text { Gaupsin sprayed } \\
\text { and sprinkling on } \\
\text { soil } 49\end{array}$ & 53 & 41 & 50 & 194 & 49.5 \\
\hline $\begin{array}{l}\text { Gaupsin sprayed 5 } \\
\text { days earlier the } \\
\text { harvesting }\end{array}$ & 52 & 45 & 51 & 196 & 49.0 \\
\hline
\end{tabular}

By productivity (Table 2), we obtained a lower harvest for NPK agronomic variant compared to NPK 0.5 agrotechnical variant, and the yield of all variants of application of Gaupsin was significantly higher than the variant of NPK according to agrotechnical regulations. The NPK 0.5 agrotechnical dose + Gaupsin sprayed is to be particularly noted, which indicates the positive effect of this preparation in terms of productivity. It should also be noted that the use of Gaupsin has virtually eliminated the alternating bearing of mandarins and we obtained quantitatively and qualitatively stable yield over the years.

Table 3. Data on storage on average, 2015- 2017

\begin{tabular}{|l|l|l|l|l|}
\hline & Variants & $\begin{array}{l}\text { Quantity of } \\
\text { fruits in pcs in } \\
\text { the beginning } \\
\text { of the } \\
\text { experiment }\end{array}$ & $\begin{array}{l}\text { Healthy fruits } \\
\text { after 15 days }\end{array}$ & $\begin{array}{l}\text { Healthy fruits } \\
\text { after 25 days }\end{array}$ \\
\hline 1 & NPK by agro.regulations & 100 & 93 & 85 \\
\hline 2 & NPK 0.5 agrotechnical dose & 100 & 95 & 87 \\
\hline 3 & $\begin{array}{l}\text { NPK 0.5 agr.dose +Gaupsin } \\
\text { sprayed }\end{array}$ & 100 & 100 & 95 \\
\hline 4 & $\begin{array}{l}\text { Gaupsin sprayed and } \\
\text { sprinkling on soil }\end{array}$ & 100 & 100 & 96 \\
\hline 5 & $\begin{array}{l}\text { Gaupsin sprayed before } \\
\text { harvesting }\end{array}$ & 100 & 100 & 100 \\
\hline 6 & $\begin{array}{l}\text { Gaupsin sprayed before } \\
\text { harvesting and spraying on } \\
\text { fruits before storage and } \\
\text { further each 15 days }\end{array}$ & 100 & & 100 \\
\hline
\end{tabular}

The main purpose of our research work was to determine the effect of Gaupsin on the storability of mandarin fruits. To this end, in the experimental period according to years (2014 - 2017) during the harvest from all variants (from model plants) we obtained 100 separate fruits of equal sizes, weighed and placed them in a specially designated storage room in conditions of $10-12^{\circ} \mathrm{C}$, and inspected them every 15 days, we counted healthy and damaged fruit, weighed, estimated the losses in weight, as well as total and natural losses. 
As can be seen from the table, in normal conditions, during 15 days in the variant of the NPK agrotechnical regulations $7 \%$ of fruit was damaged. Almost the same picture was given by the variant of NPK 0.5 dose. And in the variants where the preparation Gaupsin was used, the yield of healthy fruit was $100 \%$. The same $100 \%$ of healthy fruits were maintained at storage for 25 days, sprayed by Gaupsin before harvest, and sprayed by Gaupsin during commodity processing.

\section{Conclusion:}

Thus, the results of our studies confirm that biopreparation Gaupsin significantly reduces the major pests of mandarin plants, the tendency of increasing of soil fertility is noted, yield and natural storability of produced fruits increases. Therefore, we recommend that citrus farmers in citrus orchards use a biopreparation Gaupsin in the vegetation period by spraying on the plant once a month and 5-10 days before harvesting and on the fruit and vegetable crop, before harvesting to process the working boxes and storage containers by water solution 1:50 of Gaupsin.

\section{References:}

[1] Z. Mikeladze, V. Tsanava, N. Nakashidze. Influence of orthographic factors on citrus fruit productivity and soil agrochemical indices. Subtropical Cultures N12, 2009, pp. 254-260 (in Georgian).

[2] Z. Mikeladze, N. Kutaladze, N. Nakashidze. Dependence of storability of mandarin fruits on their mineral composition. Proceedings of the State Agrarian University of Georgia Vol. 3. N1. 3, No. 1 (50), Tbilisi 2010 pp. 41-44, ISSN 1987-6599 (in Georgian).

[3] N. Nakashidze, V. Tsanava, Z. Mikeladze, N. Kutaladze. Influence of mineral fertilizer dosage and element ratio on the storability of mandarin "Unshiu" fruit. Proceedings of Conference of the Institute of Subtropical Cultures and Tea Industry, Subtropical Cultures, 1-4 (261-264) ISSN02.07-9224 Ozurgeti, Anaseuli, 2010 pp.154 -157. (in Georgian).

[4] V. Tsanava, Z. Mikeladze, N.. Nakashidze, N. Kutaladze. Influence of mineral fertilizers on qualitative indications of mandarin fruit. Bulletin of Georgian Academy of Agriculture Science. 26ISSN1520-2010 Tbilisi, 2009, pp.333-337 (in Georgian).

[5] Mikeladze Z. R. Diagnosis of heterogeneity of soil properties in different structures of Abkhazia as a factor in the effectiveness of fertilizer application - Bulletin of Soil Institute named after Dokuchaev. Issue III. Moscow. 1987 (in Russian)

[6] Mikeladze Z. R., Gordadze K. Influence of the technological regime of commodity processing (washing + disinfection + waxing) on the commodity and storability of mandarin fruits. Thesis of the report at the Republican Scientific Conference on the problem of the citrus-growing sub-complex of the AIC of GSSR, Sukhumi - 1988 (in Russian).

[7] Mikeladze Z. R. Baratashvili D. Change in the mechanical and biochemical parameters of mandarin fruits "Unshiu" depending on their development. Thesis of the report at the Republican Scientific Conference on the problem of the citrus-growing sub-complex of the AIC of GSSR, Sukhumi - 1988 (in Russian).

[8] Mikeladze Z. R., Marshania I. I. Accelerated diagnostics of the reaction of mandarin and lemon trees on the level of nitrogen nutrition. Materials of the all-Union scientific 
and methodological seminar on improving of systems of diagnostics of nutrition of agricultural plants. Moscow. 1993 (in Russian).

[9] Mikeladze, Chebotarieva M., Godziashvili.B Status and prospects of citrus growing in the humid subtropics of Georgia. Subtropical and ornamental gardening (Scientific works of the State Scientific Institution of the All-Russian Scientific Research Institute of Floriculture and Subtropical Cultures of the Russian Academy of Agricultural Sciences) Issue 47. Sochi. 2012. (in Russian).

[10] Zavalin A. A. The use of biological products in the cultivation of field crops. Theoretical and scientific-practical journal "Achievements of science and technology", No. 08, 2011, Moscow. p. 9. https: // cyberleninka / ru / n / primenenie-biopreperatovpri-vozdelyvanii-polevyh-kultur (in Russian).

[11] Zavalin A. A. Biopreparations, fertilizers and harvest. VNIIA, 2005. -302 p.(in Russian).

[12] Tikhonovich I.A., Kozhemyakov A.P., Chebotar V.K. et al. Biopreparations in agriculture (Methodology and practice of using microorganisms in plant growing and fodder production). - Moscow: Russian Agricultural Academy, 2005. -154 p.(in Russian).

[13] Kuznetsov A.E, Gradova N.B. Scientific basis of environmental biotechnology. Moscow: Mir, 2003. (in Russian).

[14] Gabrilovich I.M. On the inhibitory effect of Bacillus subtilis and B. Brevis on putrefactive microorganisms during storage of vegetables and fruits // Abstracts of the conference "Microorganisms-stimulants and inhibitors of growth of plants and animals." Tashkent. 1989. p.8. (in Russian).

[15] Nagornaya L.V. Main diseases of apricot and biological control of their distribution in conditions of the southern steppe of Ukraine. - Journal "Scientific works of the North Caucasian Zonal Scientific Research Institute of Horticulture and Viticulture". Vol. 8. 2015. pp.183-188. (in Russian).

[16] Gavrilova A.S., Dimitrieva N.Yu. Diseases and pests of fruits. The latest preparations for protection. From the series: Urozhaykiny. Always with a crop. "Eksmo" Publishers. 2015. -128 p. (in Russian).

[17] Gaupsin: instructions for use for processing of gardens, vineyards and vegetable gardens. https:/agronomu.com/bok/3083-qaupsin-instrukciya-po-primeneniyuobrabotki-sadov-vinogradnikov-i-ogorodov.html. (in Russian).

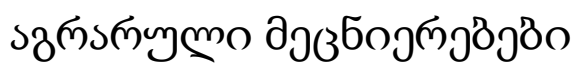

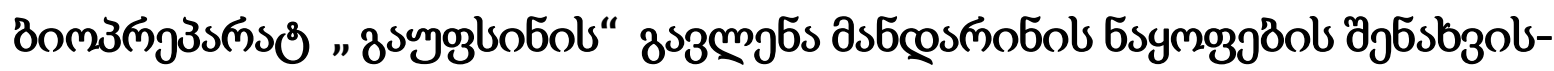

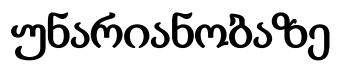

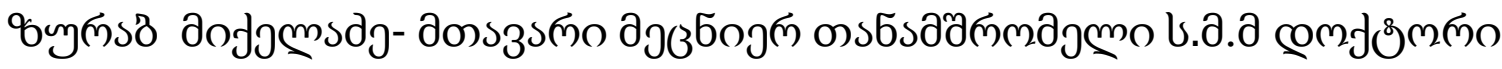

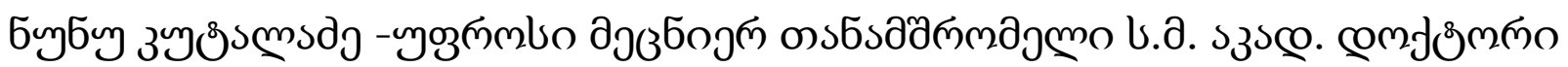

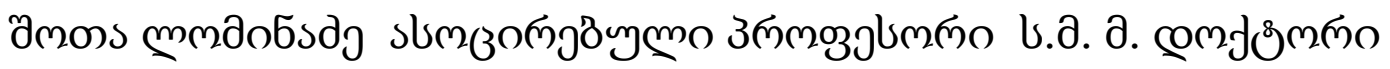

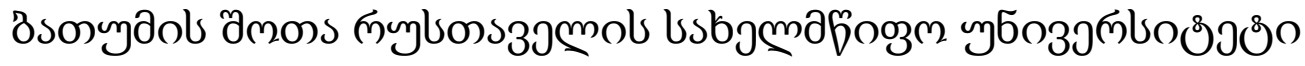

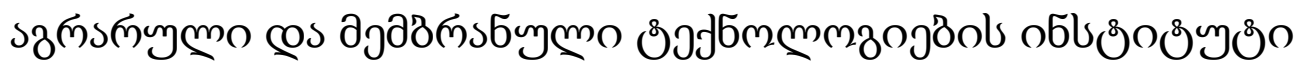




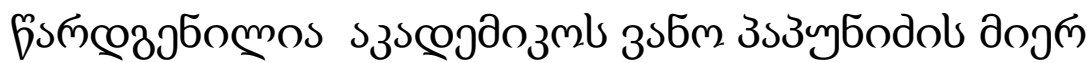

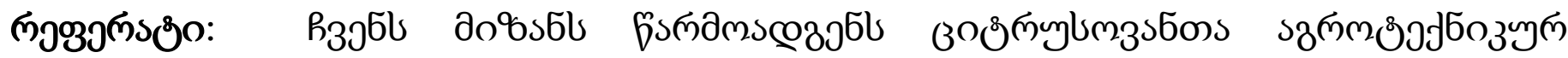

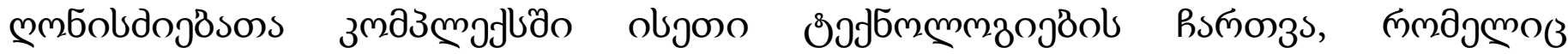

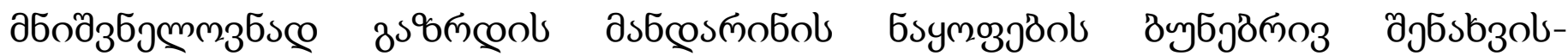

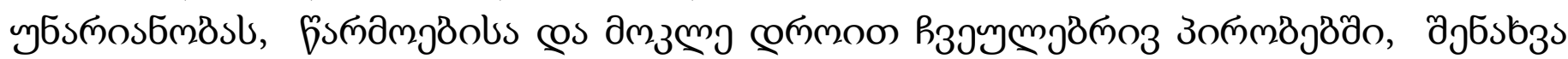

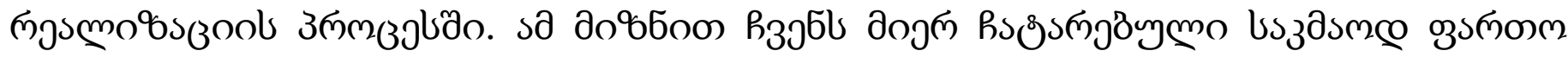

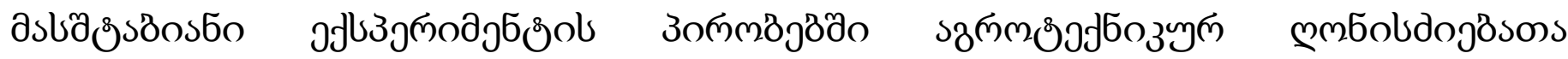

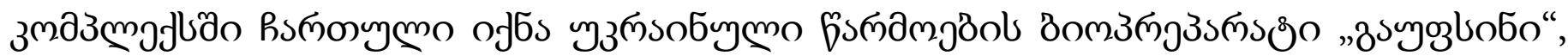

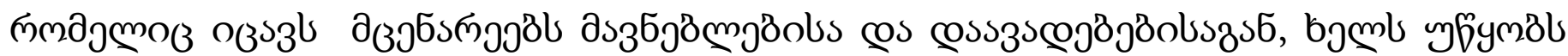

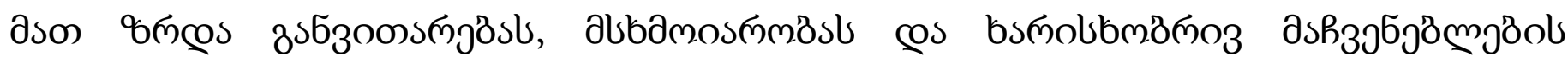

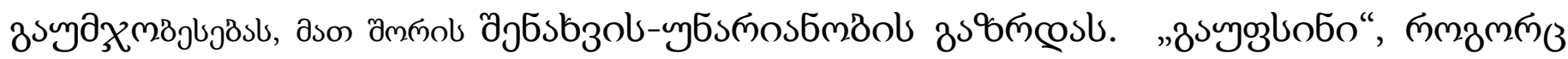

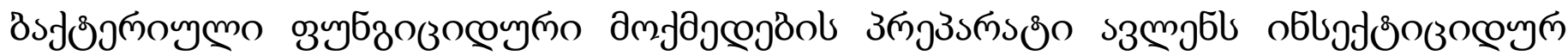

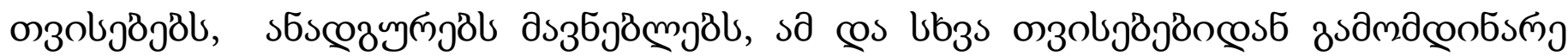

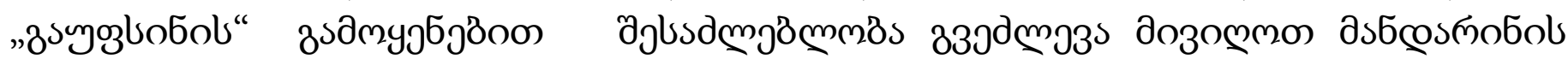

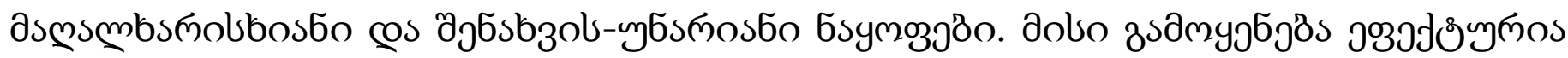

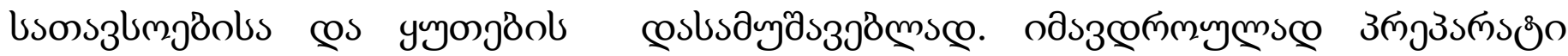

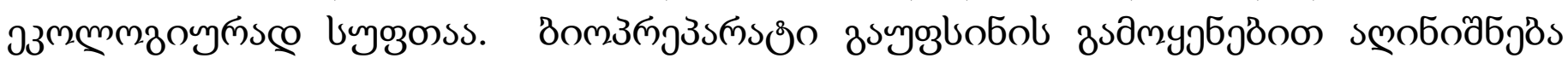

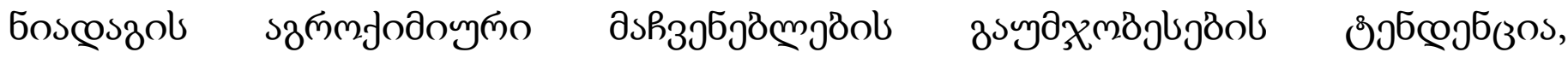

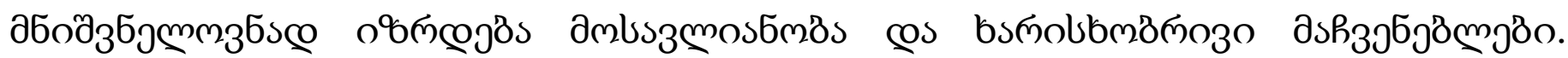

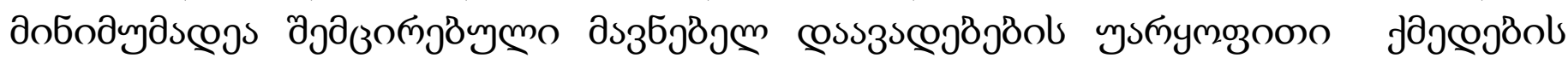

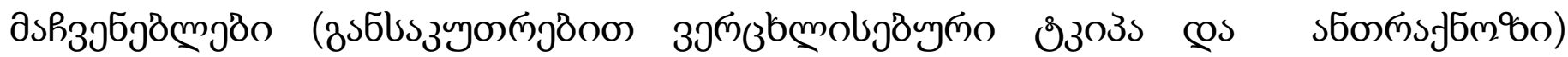

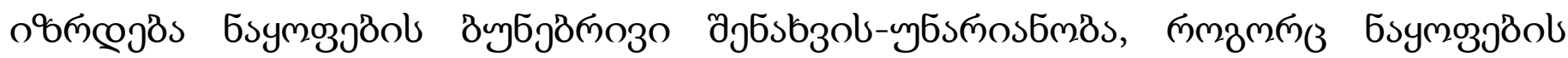

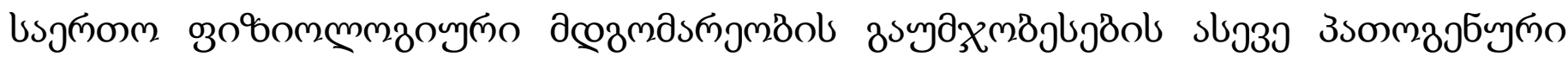

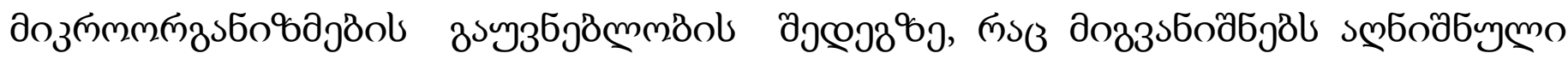

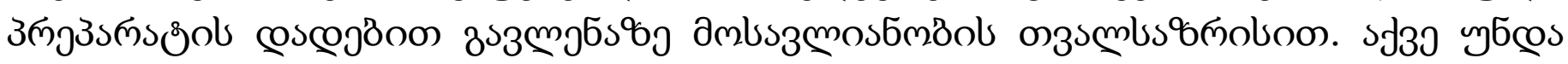

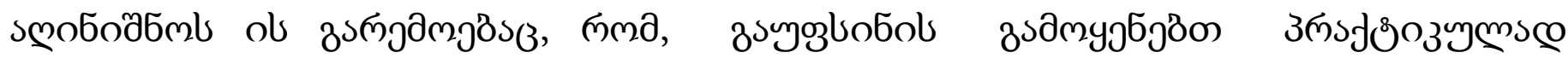

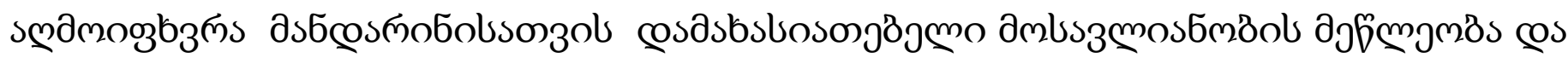

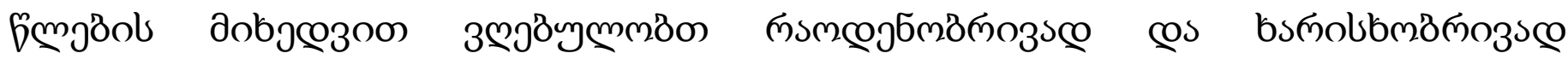
bo̊söomyn dmbşs

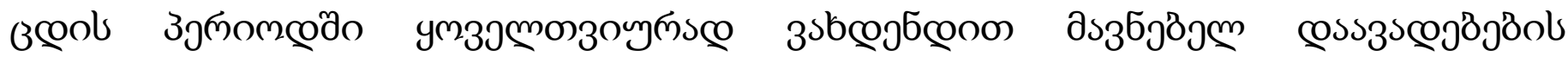

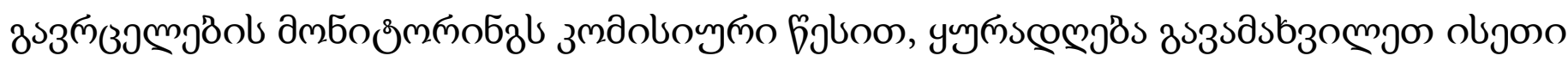

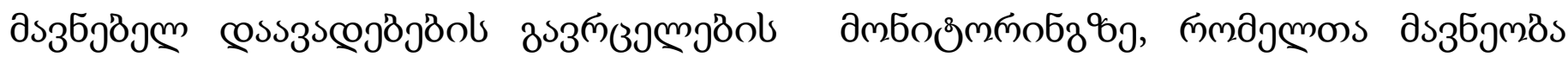

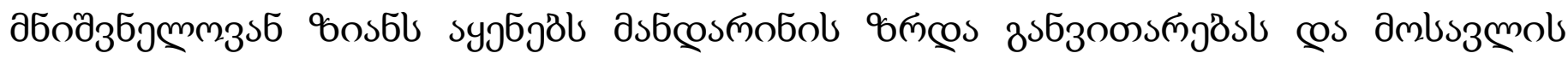

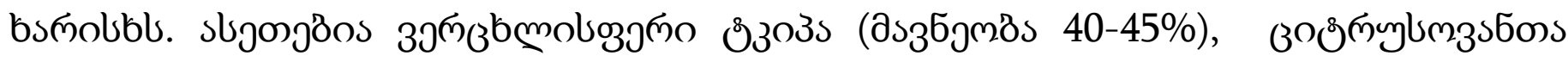

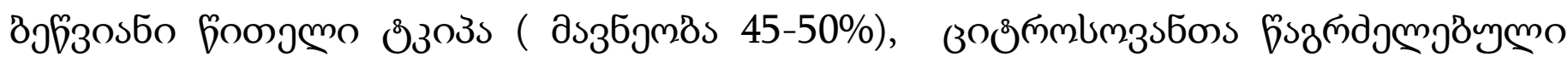

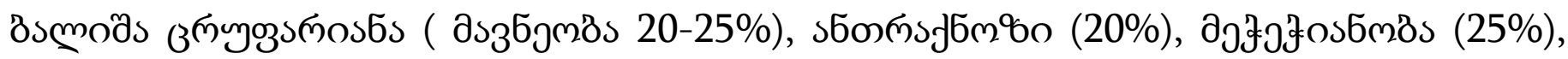

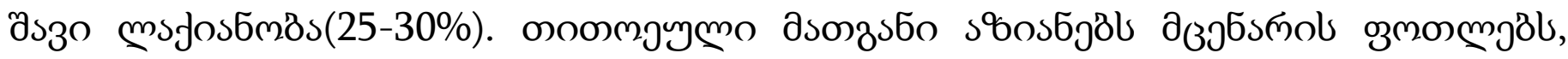




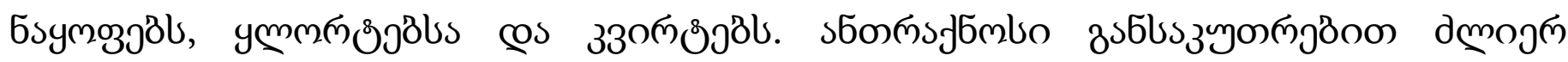

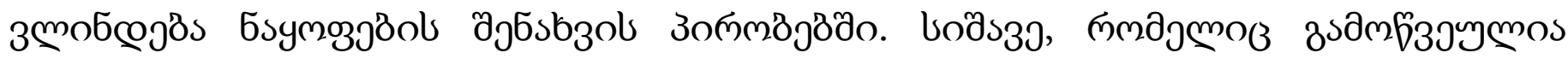

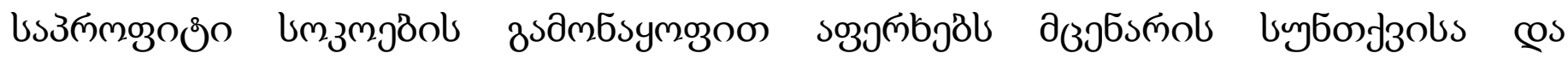

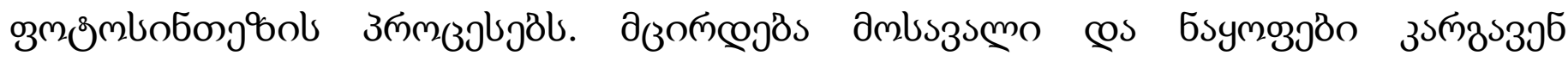

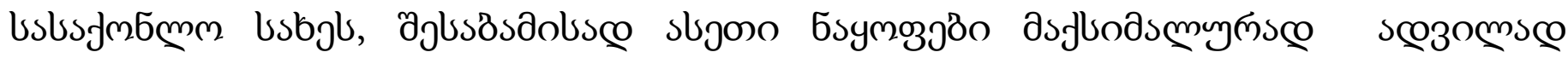

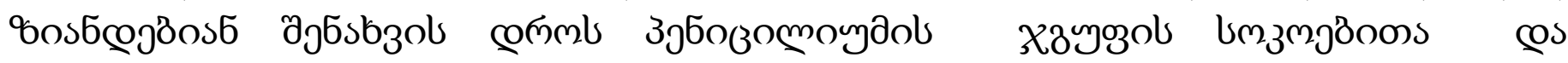

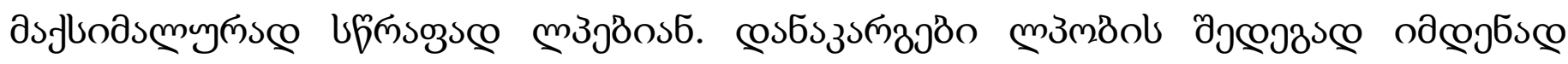

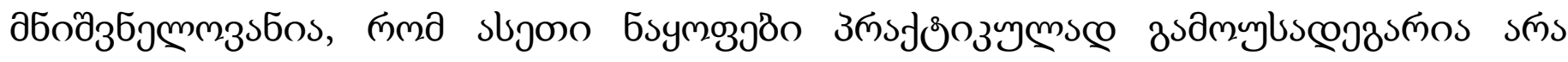

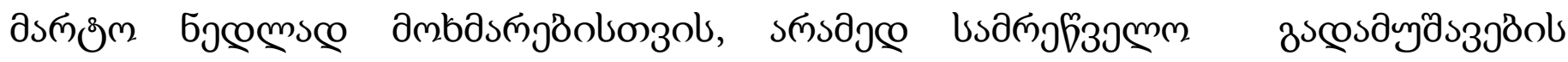

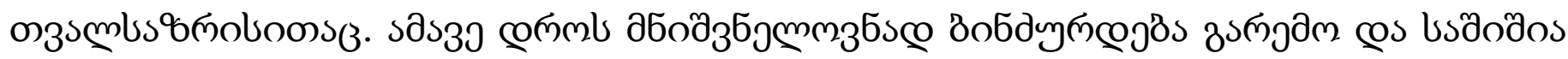

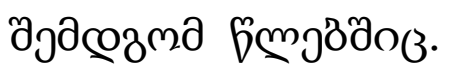

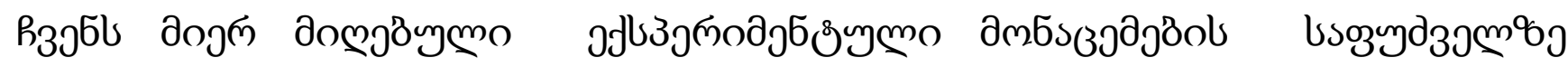

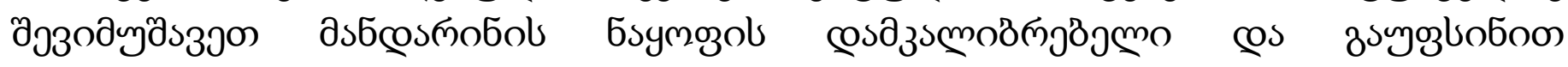

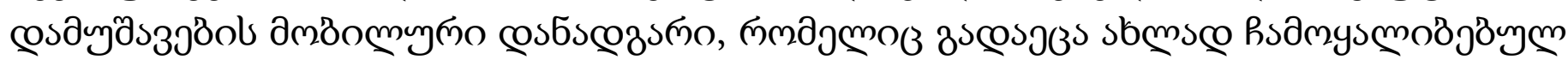

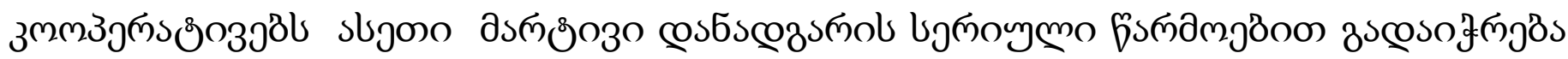

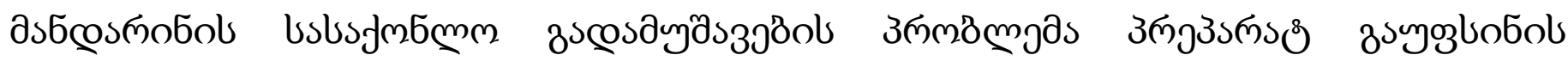

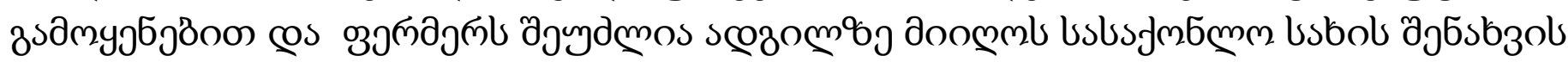

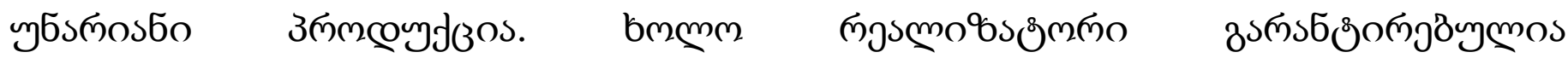

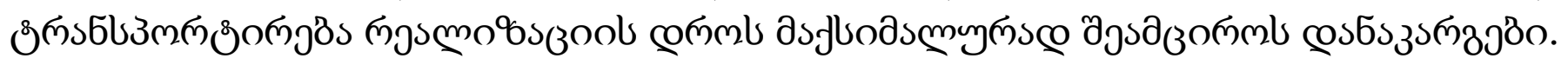

